\title{
Interests and concerns of the Army Medical Services as reflected by the publications in the Journal of the Royal Army Medical Corps 1903-2019
}

- Additional material is published online only. To view please visit the journal online (http://dx.doi.org/10.1136/ jramc-2019-001314).

Academic Department of Military Surgery and Trauma, ICT Centre, Birmingham, UK

\section{Correspondence to}

Tom Barker, Academic Department of Military Surgery and Trauma, ICT Centre, Birmingham B152SQ, UK; tombarker@hotmail.com

Received 20 August 2019 Accepted 21 August 2019 Published Online First

2 November 2019

\author{
Tom Barker
}

ABSTRACT

Introduction The Journal of the Royal Army Medical Corps (JRAMC) is published with the aim of propagating current knowledge and expertise while also acting as institutional memory for the practice of medicine within the military. This work aimed to examine how the interests of the JRAMC, and by inference the Army Medical Services, have changed over time as reflected by the articles published in the journal.

Methods A text mining analysis of the titles of all published articles in the JRAMC between 1903 and 2019 was performed. The most commonly used terms were identified and their relative frequency over the decades analysed to identify trends. Article content and contemporary events were compared with the observed trends to identify explanatory events and themes of interest.

Results Medical topics of interest centred around specific infectious diseases, particularly during the early/ mid-20th century, and trauma and battle injury. The medical specialties of surgery, anaesthetics and mental health were all well represented in nearly all decades, while primary care only came to prominence as a named specialty from the 1960s onwards. India, France, Egypt and wider Africa were the most commonly cited geographical regions, although there were spikes of interest associated with specific conflicts in the Falklands, Bosnia, Afghanistan and Iraq.

Conclusion The interests of the JRAMC have changed considerably over the years primarily driven by the geopolitical interests of Britain-in particular its colonial interests and the conflicts it has been involved in, but also by medical advances seen in contemporary society.

\section{INTRODUCTION}

The Journal of the Royal Army Medical Corps $(J R A M C)$ was launched in 1903. It publishes a range of articles from original research, reviews, historical vignettes and other invited works from all ranks and services. Its stated aim is 'not only to propagate current knowledge and expertise but also to act as an institutional memory for the practice of medicine within the military'. ${ }^{1}$ It would therefore be expected that the articles published in the JRAMC throughout its history reflect the interests of the Army Medical Services (AMS) and the military at the time, as well as those of the broader contemporary society within which it existed.

The aim of this study was to perform an analysis using text mining techniques of all article titles published in the JRAMC between 1903 and 2019 and use this to identify the most common terms and

\section{Key messages}

This study has demonstrated that text mining techniques can be successfully applied to article titles in medical journal to derive useful and interesting information about the journal contents and changing interests over time.

- There have been several observable trend changes in the interests of the JRAMC over the decades. The most significant of these include a decline publications concerning specific infectious diseases over the course of the twentieth century; and a change in geographical regions of interest according to specific conflicts and contempory British geopolitical and colonial interests.

examine how the frequency of these terms changed over time with the changing AMS interests and activities.

\section{METHODS}

A PubMed search for all articles published in the JRAMC between 1903 and 2019 (exclusive) was performed using the search criteria 'Journal of the Royal Army Medical Corps' (Journal) AND ('1903/01/01' (PDAT): '2019/01/01' (PDAT)). Records in PubMed only go back to 1945 , therefore a manual extraction of all article titles from the JRAMC archive ${ }^{2}$ was performed, with titles from 1945 onwards being cross-referenced with the PubMed database to ensure no articles were missed.

It was found that many of the article titles retrieved from the JRAMC archive had typographical errors, spelling errors or encoding errors. To fix this, titles were converted to lower case and punctuations removed to ease processing, then major errors were corrected with a semiautomated process using a custom Perl script (https://www.perl.org/). Where an article title could not be adequately deciphered the facsimile PDF copies of the article or index listing published in the JRAMC archive were consulted and the title corrected manually. Article titles identified as containing no useful information about their content (eg, editorials or forewords with no subheadings, index listings, obituaries, and so on) were also removed at this point using the same script. 


\section{Removal of stop words and word stemming}

In natural language processing, words that contribute nothing to the meaning of the text are referred to as stop words. These are typically common words such as 'the', 'a', 'by', 'and', and so on, such that an article entitled 'enterolith ileus as a complication of small bowel diverticulosis' would become 'enterolith ileus complication small bowel diverticulosis' after the removal of stop words. There is no standard list of stop words; for this analysis, stop words from the list published by the University of Glasgow Information Retrieval Service were used. ${ }^{3}$

Another common preprocessing step in text analysis is stemming - a process of reducing infected or derived words to a common root. For example, psychiatric, psychiatry and psychiatrist could all be stemmed to 'psychia' or even 'psych'. This approach allows the identification of words with a common meaning, but is not without problems. Understemming is the process whereby words with a common meaning are not reduced sufficiently to a common root and therefore relationships can be missed during analysis. Overstemming occurs when unrelated words are aggressively stemmed to a common root, leading to false positives (type I error) during analysis.

Stemming was attempted using Porter's stemming algorithm provided by the R SnowballC library, however the results were found to be poor for the medical and military terminology used in the text here. Instead, suitable stemming terms and synonyms were manually identified from examination of article titles (see the online supplementary table for a full list) and applied with the same Perl script during the preprocessing step described above. This approach allowed the replacement of related words which would not be possible by automated approaches, for example, the grouping of African countries was under the term Africa for the purposes of analysis. Obvious non-related terms were also detected during this step and excluded, for example, the word German in 'German Measles' was not stemmed with Germany since the use of the word here had no relation to an interest in matters relating to the country. This stemming process would sometimes produce article titles containing the stemmed word twice, for example, a title with words China and Chinese would be stemmed to have the word China in it twice. To prevent this doubling of the weighing of terms by a single article duplicate words were removed in the final preprocessing step. This produced the structured set of article titles, referred to in linguistics as the text corpus, upon which frequency analysis of terms was performed.

\section{Text analysis}

Articles were categorised according to the decade of publication and tokenisation, the process of breaking up a string of words into individual or groups of words or stems, was performed on the titles. Titles were broken down into single words/stems, groups of two words/stems and groups of three words/stems. For the purposes of this analysis, single words/stems will be referred to as tokens (strictly unigrams), two words/stems group as bigrams and three words/stems group as trigrams, collectively they are referred to as ngrams. Generation of bigrams and trigrams was performed according to all possible combinations, for example, the term 'Army Medical Corps' would be broken down into the two bigrams: 'Army Medical' and 'Medical Corps'.

The frequency of ngrams in the text corpus was counted, and the percentage frequency of each ngram by decade calculated (as the frequency of the ngrams divided by the total number of ngrams occurring in that decade multiplied by 100). This was done so as to avoid ngrams occurring in decades with fewer publications (such as the incomplete decade in the 1900s) being under-represented when compared with other decades. Ngram percentage frequency tables were analysed to identify frequently occurring terms, or obvious synonym groupings that might be useful to identify interesting trends. For example, the token 'egypt' was not grouped under 'africa', since it occurred with sufficient frequency to be interesting in its own right. Other less frequently mentioned African nations were grouped together to examine the interest in Africa as a whole, rather than being lost in the noise of other low-frequency tokens. This process was iterative with unidentified synonyms/stems being added to preprocessing script and the analysis repeated, to generate the final set of stems from which the final text corpus used for the analysis was generated.

Tokens were grouped into five broad areas of interest based on commonly occurring ngrams: foreign (non-European); European; medical specialty; infectious diseases; and trauma and battle injury. The percentage frequencies of the most common tokens of interest were plotted by decade to identify trends in the occurrence of specific tokens over the publication history of the JRAMC. In decades with high frequencies of a specific token, reference was made to the original articles in which the token occurred to identify the context in which it was used and possible explanations for the trend observed. All data analysis was performed using the $\mathrm{R}$ Language and Environment for Statistical Computing. ${ }^{4}$

\section{RESULTS AND DISCUSSION}

A total of 12215 articles were identified; after removal of articles with no useful tokens for analysis this was reduced to 9858 . The processed text corpus contained a total of 48278 tokens of which 8618 were unique. The most common tokens, bigrams and trigrams are shown in table 1. Many of the tokens were difficult to interpret in isolation; that terms like medical, military or army are common in the JRAMC is unsurprising and reveal nothing useful out of context, especially when it is realised they are frequently used in trigrams such as 'army medical services' or 'royal army medical (corps)'. While bigrams and trigrams are more specific and straightforward to interpret, it is easy to apply too much weight to their importance. As can be seen from table 1, a trigram only had to appear 13 times in the corpus to make it into the 20 most frequently occurring trigrams. Despite this, some tokens were interesting in themselves; the tokens 'india', 'malaria' and 'africa' clearly relate to specific geographical areas or diseases. Some tokens could be interpreted in the context of their bigrams or trigrams, for example, 'fever' was extremely common but relatively non-specific. Examination of bigrams containing the token fever demonstrated that these often referred to a specific disease, for example, enteric fever, typhoid fever, malaria fever, and so on, the most common of these were stemmed as described in the Methods section.

'Case' was the most common token in the corpus, in conjunction with 'note' (the third most common token) this reflects the frequency of case reports or series in the JRAMC, an observation confirmed by examining the most common bigrams where 'note case', 'report case' and 'unusual case' all feature in the 25 most frequent bigrams. The token 'report' was also very frequent but was not used exclusively for case reports (as demonstrated by the common trigrams 'report medical research' and 'report royal commission') and is therefore was not stemmed with case to avoid overstemming. Examining the trigrams it can be seen that the single most common case reports pertained to enteric fever and gunshot wounds. The frequency of case reports was 
Table 1 The 25 most common tokens, bigrams and trigrams in the text corpus, numbers in parenthesis denote the frequency of the ngram in the corpus. The token list was generated from a corpus with common specific bigrams reduced to their shortest stem (see the online supplementary table for a complete list), the corpus used for analysis of bigrams and trigrams had undergone selective stemming without the removal of bigrams

\begin{tabular}{|c|c|c|c|}
\hline Rank & Token & Bigram & Trigram \\
\hline 1 & case (1022) & army medical (245) & royal army medical (179) \\
\hline 2 & medical (736) & royal army (190) & army medical corps (163) \\
\hline 3 & note (587) & medical corps (163) & journal royal army (47) \\
\hline 4 & military (569) & medical service (153) & army medical service (39) \\
\hline 5 & army (555) & enteric fever (110) & $\begin{array}{l}\text { defence medical service } \\
\text { (21) }\end{array}$ \\
\hline 6 & treatment (490) & note case (100) & $\begin{array}{l}\text { mitchiner memorial lecture } \\
\text { (19) }\end{array}$ \\
\hline 7 & report (416) & medical officer (80) & south africa war (19) \\
\hline 8 & service (374) & military hospital (73) & $\begin{array}{l}\text { experience territorial } \\
\text { medical (18) }\end{array}$ \\
\hline 9 & war (347) & british army (64) & $\begin{array}{l}\text { territorial medical officer } \\
\text { (18) }\end{array}$ \\
\hline 10 & hospital (316) & south africa (64) & $\begin{array}{l}\text { war experience territorial } \\
\text { (18) }\end{array}$ \\
\hline 11 & soldier (311) & field ambulance (63) & uk armed forces (17) \\
\hline 12 & india (276) & british soldier (62) & case enteric fever (16) \\
\hline 13 & british (260) & special reference (59) & army medical college (15) \\
\hline 14 & field (260) & typhoid fever (57) & case gunshot wound (15) \\
\hline 15 & injury (259) & gunshot wound (53) & $\begin{array}{l}\text { committee royal society } \\
\text { (15) }\end{array}$ \\
\hline 16 & fever (246) & report case (53) & $\begin{array}{l}\text { medical research council } \\
\text { (14) }\end{array}$ \\
\hline 17 & malaria (245) & journal royal (47) & $\begin{array}{l}\text { reminiscences army } \\
\text { surgeon (14) }\end{array}$ \\
\hline 18 & africa (220) & general hospital (44) & $\begin{array}{l}\text { report medical research } \\
\text { (14) }\end{array}$ \\
\hline 19 & operation (204) & armed forces (42) & $\begin{array}{l}\text { report royal commission } \\
\text { (14) }\end{array}$ \\
\hline 20 & disease (200) & military personnel (42) & 21 other trigrams (13) \\
\hline 21 & wound (180) & unusual case (39) & - \\
\hline 22 & training (175) & $\begin{array}{l}\text { treatment gonorrhoea } \\
\text { (35) }\end{array}$ & - \\
\hline 23 & use (171) & army surgeon (34) & - \\
\hline 24 & trauma (167) & field hospital (34) & - \\
\hline 25 & enteric (162) & active service (32) & - \\
\hline
\end{tabular}

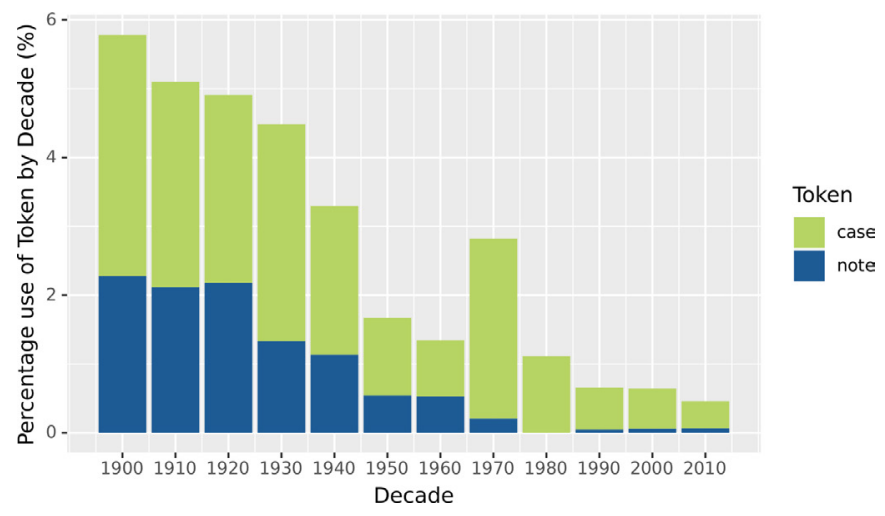

Figure 1 Stacked bar chart of the percentage frequencies of the tokens 'case' and 'note' in JRAMC article titles by decade. very much higher in the early years of the $J R A M C$, declining dramatically in the late 20th and early 21 st centuries, as shown in figure 1 . This reflects a common trend in editorial policy, with falling numbers of case reports being published in many other medical journals over the course of the 20th century. ${ }^{5}$ There was also a change in language over the decades, and while case reports continue to be published the use of the token 'note' in article titles became increasingly rare after the 1960s.

\section{Global interests}

The AMS's international interests have changed since 1903 according to the geopolitical climate and in particular British colonial interests, or conflicts they have been engaged in. A plot of the percentage frequencies of the most common tokens relating to foreign (non-European) nations and regions is shown in figure 2.

India was the most commonly referenced region in articles. Nearly all the references to India occurred before the 1950s with a large spike in articles in the 1930s. Most of the articles related to specific diseases or the practicalities of field and hospital hygiene in the colony as it was, however there was a body of articles addressing the leisure interests of a medical officer posted to India-such as elephant shooting, ${ }^{6}$ fishing ${ }^{7}$ or general travel..$^{8-10}$ Following Indian Independence in 1948 there was a collapse in interest in India and nearly all of the subsequent articles, particularly those appearing in the late 20th century, are historical pieces pertaining to the Indian Mutiny $(1857-1858)^{11-14}$ or campaign medals. ${ }^{15} 16$

Africa was the second most commonly referenced region, with two spikes of interest in the 1900s and 1910s, and again in the 1940s and 1950s. Like India, many of the articles related to specific medical matters in British colonies or protectorates. Between 1900 and 1960 Britain held at least 20 colonies or protectorates, ${ }^{17}$ and again interest in Africa waned as these states obtained independence. South Africa was the most commonly cited country in Africa (after Egypt which is considered separately), with 64 references to the bigram 'south africa'. Seventy per cent of the articles mentioning South Africa were published in the 1910s or earlier, of these 36 specifically concerned the South African War (or Second Boer War) with the trigram 'south africa war' being the most common event-specific trigram in the corpus. The South African War (1899-1902) was fought between Great Britain and two Boer Republics (the South African Republic and the Orange Free State), that it should appear so strongly in the institutional memory of the AMS is unsurprising when put into the context of the time. The South African War was the largest and most costly war the British engaged in between the Napoleonic Wars and World War I (WWI). ${ }^{18}$ Although it resulted in a British victory, losses were high on both sides and the use of guerrilla tactics by the Boer's and the British scorched earth policy and use of concentration camps were to cause lasting controversy. The Royal Army Medical Corps (RAMC) had only been formed 1 year before in 1898 and was still developing at the time of the South African War when it was called upon to manage disease and non-battle injury on an unprecedented scale. Failings in the provision of medical care were heavily criticised and triggered a Royal Commission towards the end of the war to examine the causes which led to wide-scale medical reform. ${ }^{19}$ Total British losses for the conflict were estimated at 22000 , the majority due to disease. For its part RAMC losses totalled 21 officers, 2 warrant officers and 291 non-commissioned officers and men, who are commemorated at the RAMC Memorial in Aldershot (figure 3 ). ${ }^{20}$ 

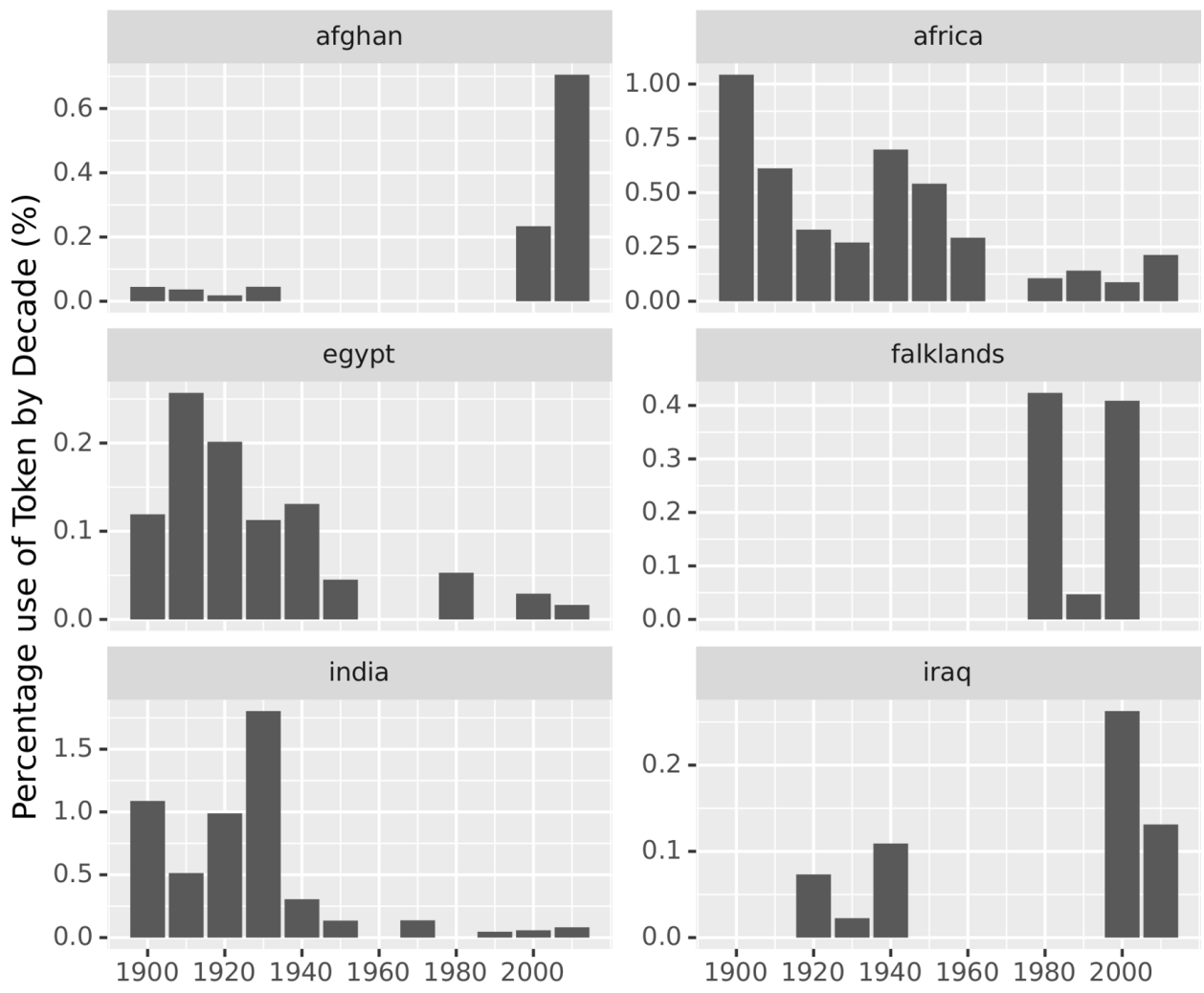

\section{Decade}

Figure 2 Bar chart of the percentage frequencies of the most common tokens relating to foreign (non-European) nations and regions in JRAMC article titles by decade. For clarity the scale of $y$-axis has been adjusted for each plot.

The second spike in interest in Africa occurred in the 1940s and 1950s, however other than being temporally related to the Second World War (WWII, 1939-1945), the articles published during that period were more disparate compared with those of the first peak of interest. Nearly all of the papers were concerned with infectious disease and sanitation, and this presumably reflects the volume of troops in Africa as part of WWII, although at least one paper addressed contemporary war issues not related

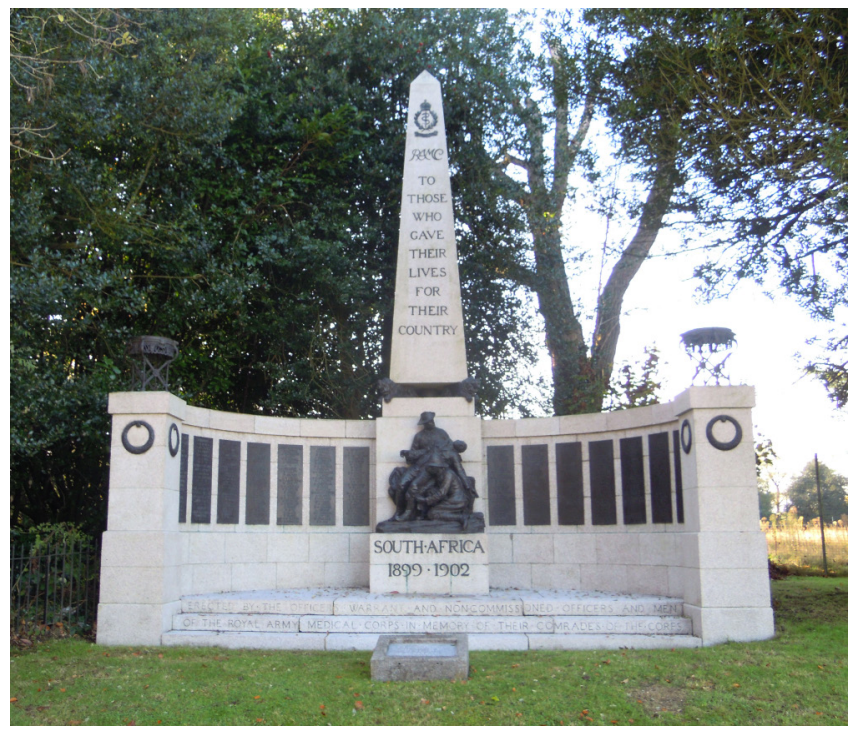

Figure 3 The Royal Army Medical Corps (RAMC) Memorial at Aldershot commemorating the officers, warrant officers and soldiers of the RAMC who lost their lives during the South African War. to disease and non-battle injury, such as the repatriation of wounded soldiers. ${ }^{21}$

Egypt was considered separately from Africa as it was cited a sufficiently large number of times to justify independent examination. Again interest in Egypt appeared to follow British occupation there, with a high volume of publications relating to Egypt in the early part of the 20th century, but waning quickly in the 1950s following the 1952 coup d'état and subsequent British departure. There was a large spike in articles relating to Egypt in 1910s, presumably as a result of increasing British presence there during WWI (1914-1918) for the purposes of defending the Suez Canal. Only one article from that time appears to be about traumatic injuries (a case series of traumatic aneurysms), ${ }^{22}$ nearly all the rest were related to infectious diseases. Schistosomiasis, or bilharzia, was endemic in Egypt and appears to have been a particular concern for British Forces there. It was cited as a priority in Lord Kitchener's annual report on Egypt in 1913 leading to the commissioning of the 1915 Bilharzia Mission in Egypt 'to investigate bilharzia disease in that country and advise as to the preventive measures to be adopted in connection with the troops, ${ }^{23}$ triggering a series of papers on the topic. ${ }^{24-27}$ WWII did not appear to generate as much interest in Egypt as WWI, and there was no observable trend in the articles published.

Other articles concerning international interests relate mainly to specific conflicts. Iraq was held under British administration until 1932 and maintained as a base until 1954, which accounts for the occasional article during the 1920s-1940s, usually on matters of tropical disease or heat illness. After 1950 there were no references to Iraq until the 2000s, coinciding with the Iraq War (2003-2011), when there was a large spike of articles, particularly concerning the management of traumatic injuries. Afghanistan (specifically the token 'afghan') was mentioned in 

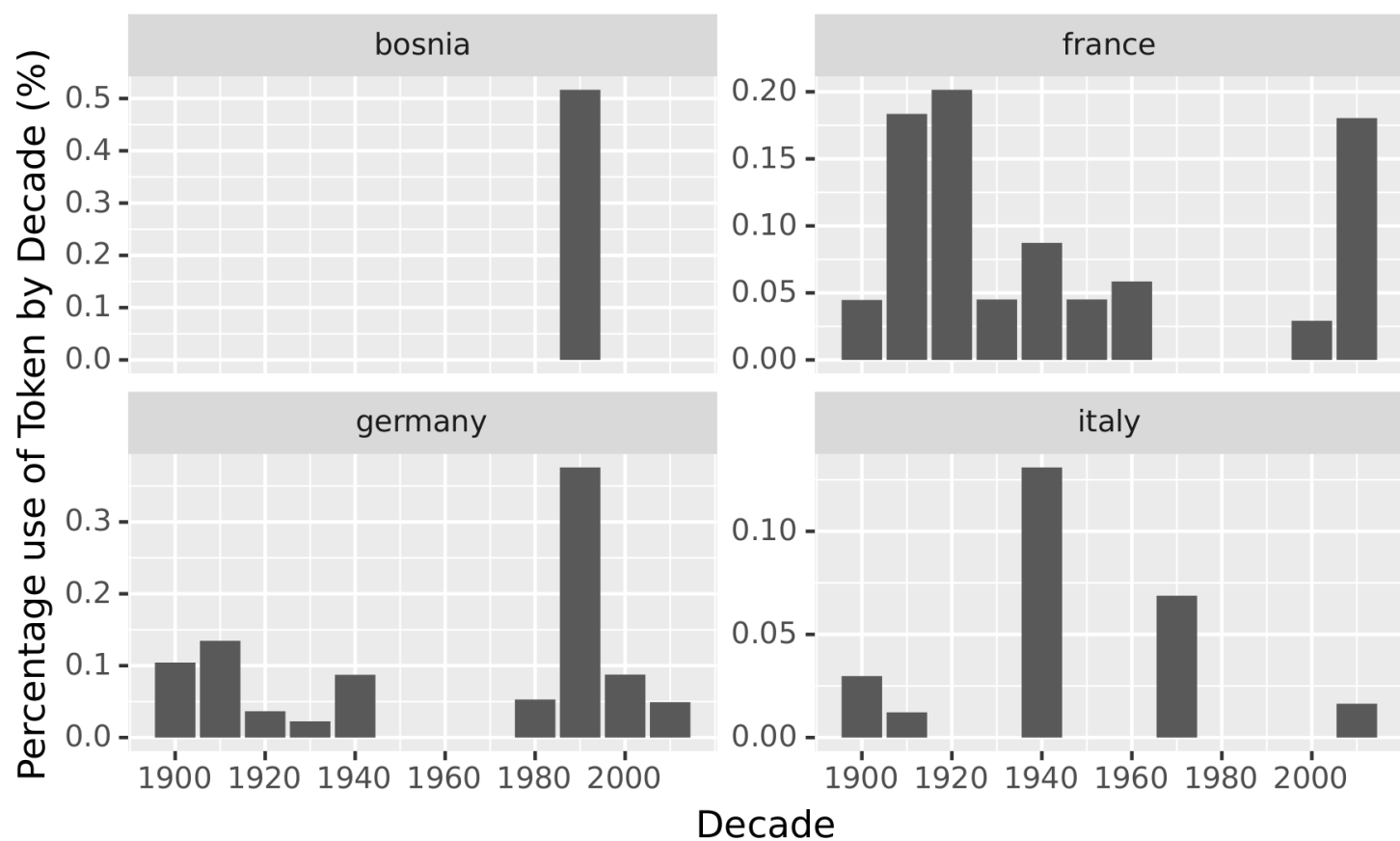

Figure 4 Bar charts of the percentage frequencies of the most common tokens relating to European countries in JRAMC article titles by decade. For clarity the scale of $y$-axis has been adjusted for each plot.

nine articles between the 1900s and 1930s, all historical pieces relating to the first (1839-1842), second (1878-1880) and third Anglo-Afghan Wars (1919). After this Afghanistan is not mentioned until the 2000s when eight articles were published followed by a further 44 in the 2010s, coinciding with British involvement in the War in Afghanistan (2001-2014). Interestingly the range of topics addressed by these articles is much more diverse than those published for Iraq. While trauma still predominated, anaesthetics were well represented, along with infectious diseases and consideration of planning and ethical issues. The Falkland Islands were not mentioned in any article titles until the 1980s despite de facto British sovereignty there since 1833 . Following the Falklands conflict in 1982, eight papers were published in the 1980 s related to the campaign. This interest seemed short lived with only a single paper mentioning the Falklands being published in the 1990s, an isolated case report on basal cell naevus syndrome. ${ }^{28}$ In the 2000 s there were a further 13 papers published with titles containing the token Falklands, however the majority of these were part of a 25 th anniversary retrospective review of the conflict and did not represent a renewed interest in the Falklands per se.

\section{European interests}

Four European countries were cited frequently enough to generate data for analysis: France; Germany, Italy and Bosnia. A plot of the percentage frequency of the tokens relating to these countries is shown in figure 4.

As might be expected for European powers heavily involved in the two world wars there were spikes in interest in France and Germany around the 1910s and 1920s, although notably not for Italy during this period, and again in the 1940s to a lesser extent but this time including Italy. Unlike nations outside of Europe, many of the articles published during this period are clearly and directly related to the delivery of healthcare in war. For the period of WWI many of the articles concerning France were related to the structure and delivery of medical services, there were also several articles describing the management of traumatic injuries and a couple describing a new condition referred to as 'trench fever', ${ }^{29} 30$ a disease recognised towards the end of the war to be caused by the bacillus Bartonella quintana found in the stomach walls of the body louse, and estimated to have affected between a $20 \%$ and $30 \%$ of British soldiers on the Western Front. ${ }^{31}$

Articles about Germany in WWI were more concerned with broader issues relating to the German Army and their campaigns, however there also were a couple of articles by RAMC officers describing experiences of Germany prisoners of war camps ${ }^{32} 33$ and curiously a translation of German standing orders on the feeding of prisoners of war in German camps. ${ }^{34}$ Between the 1940s and 1980s no articles were published with the token 'germany' in the title, however in the 1990s the largest volume of papers in any decade about Germany was published. Every one of these papers were related to primary care, with over half of them discussing issues of antenatal or paediatric care. This is a reflection of the expansion of British Forces Germany (BFG), with associated civil servants and dependants, during the Cold War and the healthcare issues seen as a result of that. With the reduction in the size of BFG in the mid-1990s, following the end of the Cold War and the Options for Change defence review, there was a dramatic fall in the number of articles concerning Germany, although most still concerned issues of primary care.

France demonstrated a similar pattern to Germany with relatively little described about it after WWII, before a flurry of papers in the 2010s. The cause of this appears to be unique in the history of the JRAMC and is driven almost entirely by papers coming from France and concerning French military medical matters. Although this body of work may not represent the specific interests of the AMS per se, it does demonstrate a move towards international collaboration-particularly with French partners.

Discussion of Bosnia in the JRAMC was uniquely isolated to a single decade. The country was not mentioned in any article title at any point except the 1990 s when it accounted for over $0.5 \%$ of all tokens from articles published in that decade. All of the 


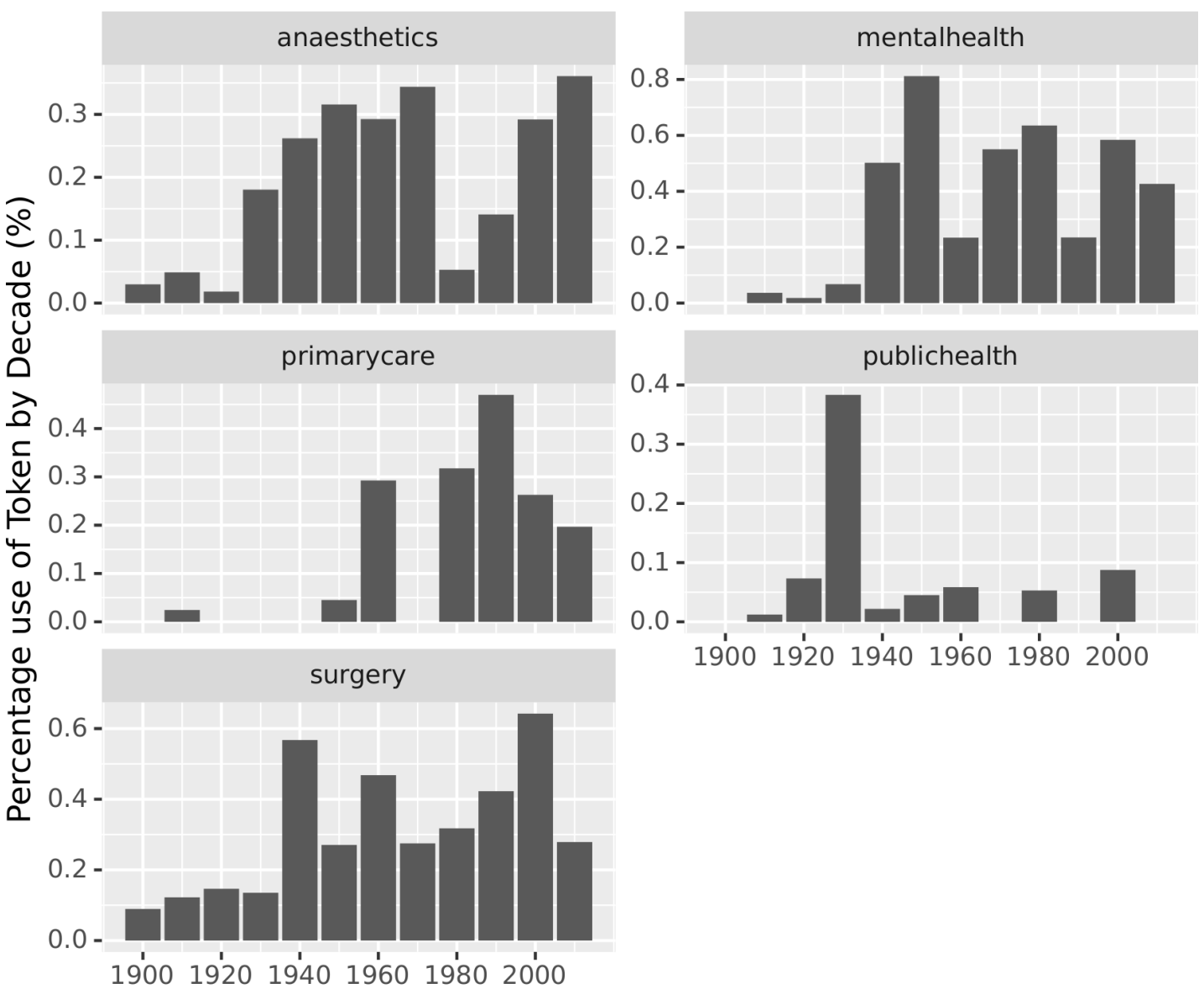

Decade

Figure 5 Bar charts of the percentage frequencies of the most common tokens relating to medical specialties in JRAMC article titles by decade. For clarity the scale of $y$-axis has been adjusted for each plot.

papers concerned British activity as part of North Atlantic Treaty Organization-led Stabilisation Force in Bosnia and Herzegovina, during Operations RESOLUTE, LODESTAR and PALATINE.

\section{Medical specialties}

Assessment of the representation of individual medical specialties in the JRAMC was difficult. Many papers are published in a specialty field without mentioning the specialty itself-as already discussed in relation to the number of primary care papers concerning Germany in the 1990s. The results here present the frequency of commonly occurring tokens identifiable as distinct medical specialties, namely mental health, primary care, public health and surgery. Medical specialties are not considered as the token 'medicine' was too broad, and medical subspecialties did not appear with sufficient frequency for trends to be identified. A plot of the percentage frequencies of tokens relating to medical specialties is shown in figure 5 .

The importance of psychiatry and mental health within the AMS is demonstrated by the fact that the 'mentalhealth' token received more direct citations than any other specialty in every decade after the 1930s. There were three spikes of interest in mental health corresponding to major conflicts: WWII in the 1940s/1950s where there was particularly large interest; the Falklands War in 1980s; and the Iraq and Afghan conflicts in 2000s. Interestingly there was no spike of interest in mental health with either WWI or the South African War. This is probably not surprising as post-traumatic stress disorder was poorly understood in the early part of the 20th century and was at times viewed as either an entirely physical condition manifesting from the concussive effects of repeated blast exposure (hence the term 'shell shock'), a 'lack of moral fibre' or 'plain cowardice'. It has been said that such was the fear in high command that the condition might be contagious in the ranks so as to cause a complete collapse in fighting power that there were active attempts to avoid medicalising the issue. ${ }^{35}$ However, this generalisation is probably unfair. In the JRAMC there was certainly an interest in the condition, in the 1910s alone the term 'shell shock' appears in the titles of six papers, ${ }^{36-41}$ war neurosis and psychosis in another, ${ }^{42}$ and there was even an early consideration in 1916 on what 'neurasthenia' might cost the state. ${ }^{43}$ An examination of these papers demonstrates that a mental or emotional component to the condition was recognised at the time, although not as we would understand it today under the umbrella of mental health or military psychiatry which is why it appears to be represented so poorly in the analysis here.

References to surgery appeared in every decade of the JRAMC's publication history as might be expected. Articles relating to surgery between 1903 and 1940 mostly concern case reports or general descriptions of surgical technique. There was a spike of interest during the 1940s associated with WWII and a shift in emphasis to discussing problems of field surgery, particular in the desert, and the organisation of medical services. There was another spike of publications in the 1960s, although the reason for this interest is unclear as the articles are disparate in nature with no unifying trend. There was a further peak in the 2000 s at the time of the Iraq and Afghan Wars mostly concerned with 
trauma and surgical subspecialties, especially maxillofacial and plastic surgery.

Anaesthetics, like surgery, appeared in every decade of the JRAMC's history; it had two peaks of interest: the first beginning in the 1930s and continuing into the 1970s, and the second in the 2000s and 2010s. It is not clear what the explanation for this was, however the period of 1930-1980 was a time of tremendous advances in the field of anaesthetics many of which are referenced in articles of the JRAMC at the time, including: the use of tribromoethanol (Avertin) and evipan sodium as sedatives in the $1930 \mathrm{~s}^{444}$; the introduction of curare and the routine use of endotracheal intubation in the $1940 \mathrm{~s}^{46-48}$; the synthesis and use of halothane in the $1950 \mathrm{~s}^{49}$; and the introduction of ketamine in the $1970 \mathrm{~s} .{ }^{50}$ The reason for the second peak does not have an obvious cause but appears to be associated with rise in interest in anaesthetics in the military with sustained publication of large number of review articles and papers covering a broad array of anaesthetic interests.

Examining the trends in primary care it can be seen that there was very little mention of 'primarycare' and associated synonyms until the 1960 s when a large number of articles started to be published. This is not to say that there was no interest in primary care issues before then, as there certainly was, but that these issues were not considered in a unified way under the domain of single specialty. The Royal College of General Practitioners was not founded until $1952^{51}$ and the term primary care did not come into common use until the $1960 \mathrm{~s},{ }^{52}$ which would explain the lack of publications directly referencing primary care or general practice before this. Following this the interest in primary care (as directly referenced in article titles) has continued ever since with a noticeable peak in the 1990s. The reason for this spike in interest in the 1990s is unclear from the article titles published at the time but may be related to the large volume of primary care articles concerning Germany in the 1990s as discussed previously.

Public health has always been a topic of interest in the JRAMC, although in the early years this was typically under the guise of environmental health or sanitation. Analysis of 'publichealth' as token produced a surprising result of low but sustained levels of publications but with a very large spike in the 1930s. The reason for this was revealed on examining these articles which proved to be a series of editorials in the late 1920s and 1930s discussing the state of public health of the nation. These publications continued regularly for a decade and then abruptly stopped.

\section{Infectious diseases}

Infectious diseases were another common theme in JRAMC articles. The eight most common distinct diseases in order of frequency were identified as: malaria, enteric (fever), typhoid, dysentery, syphilis, gonorrhoea, tuberculosis and leishmaniasis. A plot of the percentage frequencies of the most common infectious disease tokens is shown in figure 6.

Malaria was far the most common single disease about which papers were written. Interest in malaria peaked in the $1930 \mathrm{~s}$ and many of the papers concerned the issue of malaria in India, corresponding to the peak of interest in the Indian subcontinent in the JRAMC discussed previously. The fall in publications relating to malaria from the 1940 s onwards mirrors that of publications about India, although whether these two are related is unclear. 'Enteric' (fever) and 'typhoid' were next most commonly featured infectious disease tokens. Typhoid is caused by the bacillus Salmonella typhi, and is the most common cause of enteric fever. This fact was starting to be appreciated at the turn of the 20th century, ${ }^{53}$ and possibly accounts for the rapid decline in papers with titles containing the token 'enteric' in the 1910s, while references to typhoid went up in that decade. There was a secondary spike in papers using enteric in the title in the 1950s although this was driven almost completely by a large series of articles entitled 'Studies on Urinary Carriage of Enteric Group Organisms'. ${ }^{54-61}$ Typhoid was a common topic until the 1950 s with a peak of interest in the 1930s. Many of the papers from this decade were concerned with typhoid in India, and like malaria fall quickly in concert with the declining interest in India.

Examining figure 6, the key observation is that the most commonly cited infectious diseases are of much less interest to contemporary military medical practice. This is confirmed by plotting the combined percentage frequencies of all eight of the most commonly cited infectious diseases (shown in figure 7). This shows a steep decline in publications related to these diseases after the mid-20th century such that the frequency of these tokens in the 2010 s was less than $7 \%$ of that in the 1900 s. This decline in interest mirrors developments in the understanding and treatment of these conditions: falling rates of typhoid and dysentery deaths in the 1940s with improved sanitation and the introduction of antibiotic treatment ${ }^{6263}$; and a reliable treatment for syphilis and gonorrhoea following the discovery of penicillin in 1928 and its widespread use with the development of industrial manufacturing processes in the 1940s. ${ }^{64}$ Two disease processes did not follow this trend-tuberculosis and leishmaniasis. Interest in tuberculosis appears to have waxed and waned over the JRAMC's history, perhaps because more than any other condition discussed here tuberculosis has experienced several major advancements in treatment in the 1940s, 1950s and 1970s, but still remains a problem today. ${ }^{65}$

Leishmaniasis deserves special mention for the contributions made by members of the AMS to its discovery. The causative organism of visceral leishmaniasis was first described in 1903 by William Leishman (1865-1926), a pathologist and RAMC officer, who went on to become director general of AMS. Leishman identified oval bodies in the spleen of a private soldier who died after being invalided back to Netley Hospital, Hampshire, from a station in Dum Dum, India-hence the alternative name for Leishmaniasis of Dum-Dum fever; it is also the location where Neville Bertie-Clay developed the eponymous 'dumdum' bullet. Leishman, however, did not fully appreciate what he saw and mistakenly identified the parasites as altered trypanosomes. ${ }^{66}$ It was Charles Donovan (a medical officer in the Indian Medical Service) who correctly identified the Leishman bodies as new genus and as the causative organism for Kala-azar (meaning black fever in Hindi), as it was then known. This caused some controversy over the naming of the parasite, which was settled by Ronald Ross, another former medical officer with the Indian Medical Services who won the Nobel prize for his work on the life cycle of the malaria parasite, who gave attribution to both Leishman and Donovan in suggesting it be called Leishmania donovani. ${ }^{67}$ This historical perspective is helpful when examining the pattern of leishmaniasis references in the corpus. There was some interest in the 1900s and 1910s as the causative parasite was identified and its significance understood, after which there was a trickle of papers until the 1960s when there was a surge in publications on the topic. The reason for this can be recognised if it is understood that this was the centenary of the Leishman's birth and there was a retrospective assessment of the man and his contribution to the understanding of leishmaniasis. In the 1970s, there was nothing published before an even bigger number of papers appeared in the 1980s. These papers 


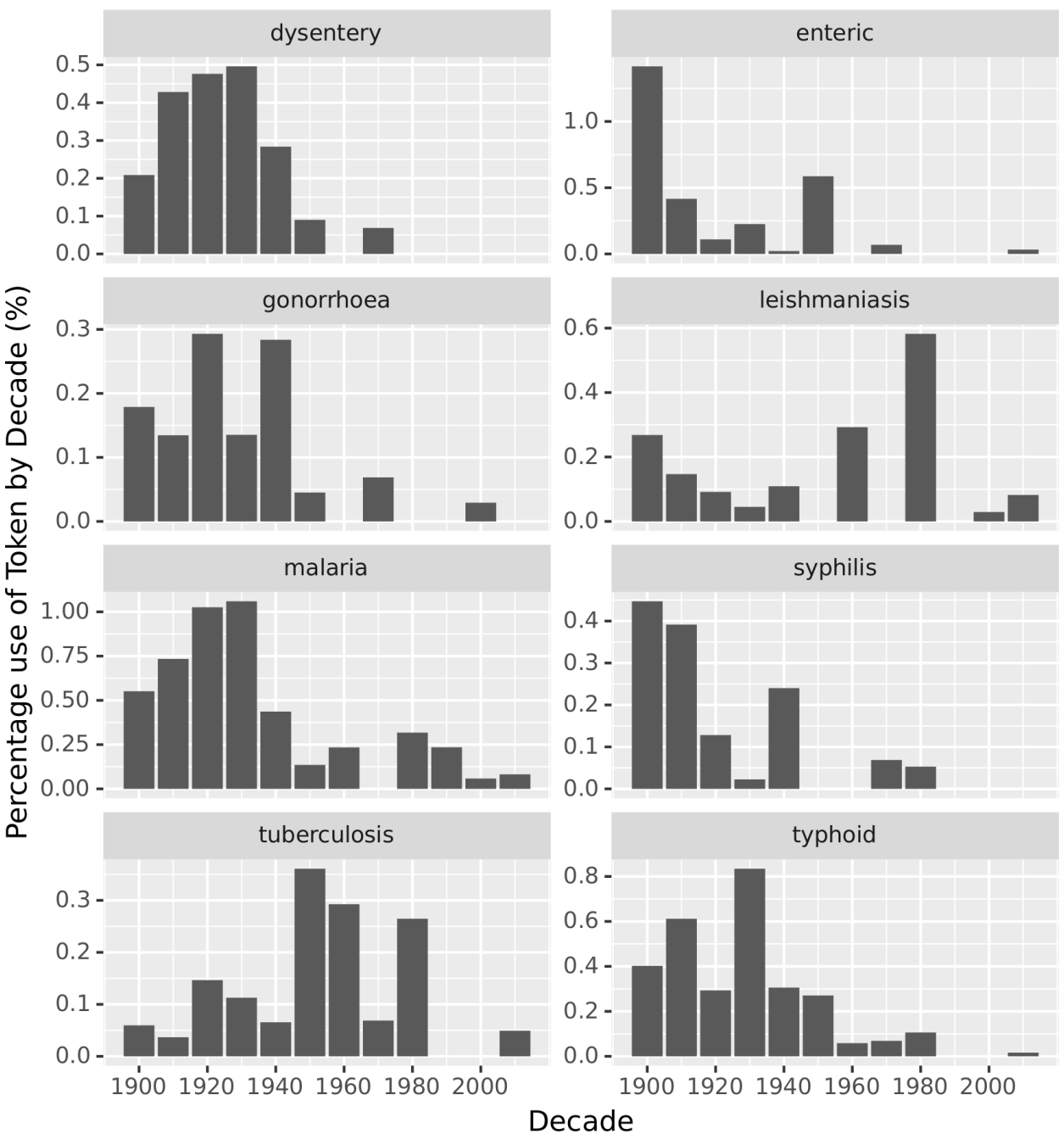

Figure 6 Bar charts of the percentage frequencies of the most common tokens relating to infectious diseases in JRAMC article titles by decade. For clarity the scale of $y$-axis has been adjusted for each plot.

appeared as part of a centenary symposium on the topic this time celebrating the first known description of the parasites in a case of cutaneous leishmaniasis by another Indian Medical Services doctor, David Cunningham, in $1885 .^{68}$

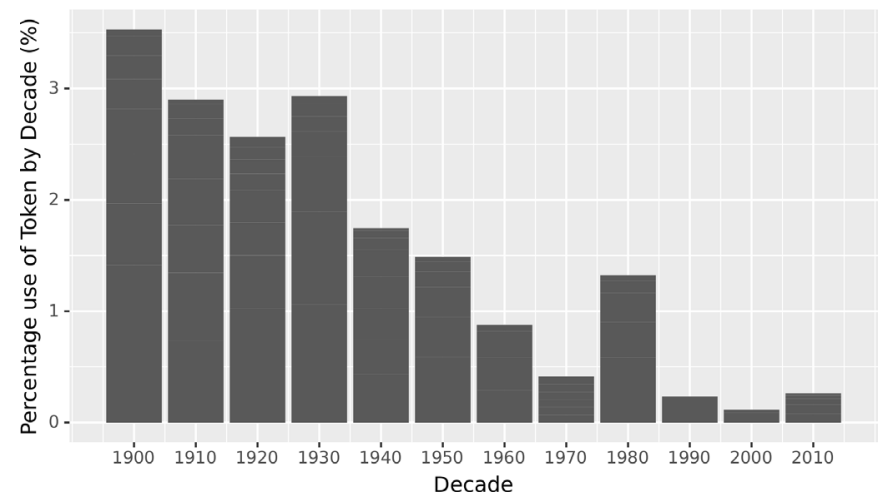

Figure 7 Bar chart of the combined percentage frequencies of the tokens relating to the eight most common infectious diseases in JRAMC article titles by decade.

\section{Trauma and battle injuries}

Analysis of the most common tokens associated with trauma or battle injury (see figure 8) showed the opposite pattern to infectious disease; the tokens 'blast', 'injury' and 'trauma' all had relatively few references during the early part of the 20th century, gradually increasing especially during the late 20th century and peaking in the 2000s and 2010s during the Iraq and Afghan conflicts. Surprisingly, these tokens did not demonstrate a temporal association with major conflicts, other than the very dramatic peaks seen in all three during the 2000s and 2010s.

The token 'gunshot' was curious as it demonstrated an opposite trend to other trauma-related tokens, with a peak of interest in the 1900s and 1910s, presumably in association with the South African War and WWI but then dropping to relatively low levels, although there was a slight increase in references associated with WWII and the Iraq and Afghan conflicts. That there should be significant interest in gunshot wounds during the First World War is no surprise. Gunshot wounds were highly prevalent and this was a period where major advances in wound management were occurring, epitomised by the technique described by Winnett Orr, an American surgeon who developed a method of cleaning, dressing and immobilising wounds during his experience with the Medical Corps of the American Expeditionary Forces in France. WWII saw equally significant developments in the understanding of wound ballistics and missile 


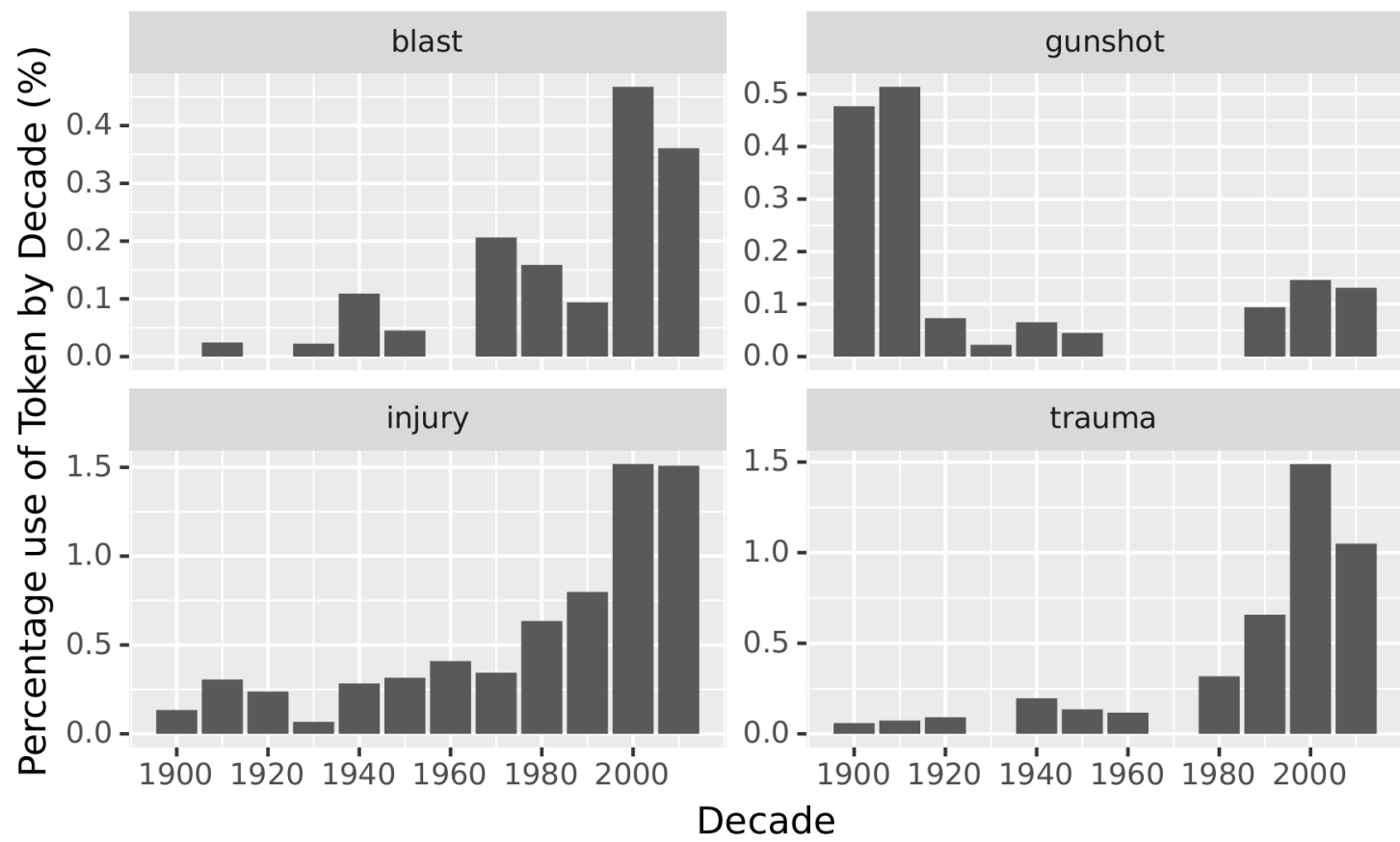

Figure 8 Bar charts of the percentage frequencies of the most common tokens relating to trauma and battle injury. For clarity the scale of $y$-axis has been adjusted for each plot.

injury enabled by the developments in high-speed cameras and $\mathrm{X}$-ray techniques, ${ }^{69}$ yet this does not appear to have generated the same level of interest in the AMS. Perhaps it is because these studies were primarily aimed at improving the offensive capabilities of weapons rather than aiding in the care of their injuries, and hence generated seemingly little interest in the medical community.

Considering the trend of interest in gunshot wounds, the pattern of publications concerning blast injuries is not as might be expected. Interest only started to develop after the 1940s and even then it was initially low. It seems strange that WWI, an era that saw the introduction of widespread use of high-explosive shells and gave birth to the term 'shell shock', should have so little interest in blast injury. This is perhaps related to the way the understanding of blast injury has developed over the course of the 20th century. While it is probably safe to say that the first true descriptions of blast injuries as a unique entity originate from WWI, the phenomenon was poorly understood and not widely recognised. It was only after the 1950 s that there were significant efforts in the field of blast injury research leading to our current understanding of the physiological mechanism of injury and medical management. ${ }^{70}$

\section{Study limitations}

The major limitation of this analysis is that it only considered words appearing in the title of articles. While this is sufficient to identify the main themes, most of the context of papers is contained within the body text. Analysis of the whole text of articles would provide a much bigger corpus upon which more sophisticated analysis could be performed, and would allow inclusion of articles excluded in this study due to their titles containing no useful interpretable information. Unfortunately, most of the articles in the JRAMC archive do not exist in machine readable format at present, which means such an approach is not possible. The smaller text corpus of just article titles also has the problem that the relative weight of topics can be skewed by small collections of unusual articles. This was seen with editorial decision in the 1930s to publish a long running series on public health and the anniversary publications on the Falklands conflict and leishmaniasis. Fortunately, these anomalies were easy to identify on examination of the original articles. A more subtle problem was with the identification of related topics in article titles using different terminology. An attempt was made to overcome this through the iterative identification of stems/synonyms for commonly identified terms. However, with over 8000 unique tokens and many more bigrams and trigrams this approach was by no means comprehensive, and terms with multiple synonyms occurring in small numbers may have been missed. Some of the synonym groupings could be done differently, such as the geographical grouping of South East Asia and Africa, however all synonym groups are fully explained in the methodology and the results should be interpreted in the context of these decisions. Using different synonyms might yield different results, but would not invalidate the results presented here.

\section{CONCLUSION}

The interests of the JRAMC, and by inference the AMS, have changed over the years according to the geopolitical interests of Britain-in particular its colonial interests during the first half of the 20th century, the conflicts in which it has been involved and the changes in medicine seen in contemporary society.

Infectious diseases, which occupied a huge mind share in the early 20th century, declined in interest from the 1940s with the introduction of effective treatments and with the British withdrawal from its colonies in India and Africa. The opposite pattern was seen in trauma and battle injuries, which although always important in conflict saw a large surge in interest in the first two decades of the 21st century associated with the Iraq and Afghan conflicts.

Many of the trends observed here were predictable, but this is the first time they have been objectively assessed and quantified. Through this analysis, several other patterns, perhaps less obvious to contemporary readers of the JRAMC, have emerged: the enduring importance of mental health to the AMS; the importance 
of primary care in 1990s Germany; the isolated significance of British operations in Bosnia and Herzegovina; and the identification of the main conflicts that have shaped AMS interests, including the usual suspects of WWI, WWII, the Falklands, Iraq and Afghan conflicts, and the South African War right back at the turn of the 20th century and the foundation of the journal.

Contributors TB is the sole author and responsible for all elements of this work.

Funding The authors have not declared a specific grant for this research from any funding agency in the public, commercial or not-for-profit sectors.

Competing interests None declared.

Patient consent for publication Not required.

Provenance and peer review Commissioned; internally peer reviewed.

Data availability statement Data are available upon reasonable request.

ORCID iD

Tom Barker http://orcid.org/0000-0002-3444-7391

\section{REFERENCES}

1 About | Journal of the Royal Army Medical Corps [Internet], 2019. Available: https:// jramc.bmj.com/pages/about/

2 Archive | Journal of the Royal Army Medical Corps [Internet], 2019. Available: https:// jramc.bmj.com/content/by/year

3 University of Glasgow Information Retrieval Resources [Internet]. Univ Glasg Inf Retr Resour 2019 http://www.ir.dcs.gla.ac.uk/resources/linguistic_utils/stop_words

4 R Core Team. R: a language and environment for statistical computing [Internet]. Vienna, Austria: R Foundation for Statistical Computing, 2019. https://www.R-project. org

5 Mason RA. The case report - an endangered species? Anaesthesia 2001;56:99-102.

6 Gillespie F. An elephant shoot in southern India. J R Army Med Corps 1930;54:53-64.

7 Thompson T. Some fishing notes from the UP, India. J R Army Med Corps 1930;54:220-30.

8 Clarke L. By rail and road in India. J R Army Med Corps 1932;58:219-31.

9 Bagshawe H. Another bit of India. J R Army Med Corps 1928;50:59-68.

10 Clarke L. Eastwards home from India. J R Army Med Corps 1930;55:302-14.

11 Starling P. The indian mutiny 1857 - 1858. J R Army Med Corps 2010;156:104-5.

12 Starling P. The indian mutiny - part 2. J R Army Med Corps 2010;156:176-7.

13 Starling P. The indian mutiny - part 3.J R Army Med Corps 2010;156:262-3.

14 MacLennan A. Echoes from the Past: "A Medical Officer in the Mutiny" Part I. Being the experiences of Francis William Innes, Surgeon 84th Foot in India (1857-58). J R Army Med Corps 1970:116:206-15.

15 Anon. Indian general service medal 1854-1895. J R Army Med Corps 2007;153:73.

16 Anon. Indian mutiny medal. J R Army Med Corps 2007:153:142.

17 Havinden M, Michael A, Meredith D. Colonialism and development: Britain and its tropical colonies, 1850-1960. Routledge, 2002.

18 The Editors of Encyclopaedia Britannica. South African war [Internet]. Available: https://www.britannica.com/event/South-African-War

19 Royal Commission on South African Hospitals. Report of the Royal Commission appointed to consider and report upon the care and treatment of the sick and wounded during the South African campaign: presented to both houses of Parliament by command of her majesty. London: Her Majesty's Stationery Office, 1901.

20 Anon. The unveiling of the South African war memorial by his majesty the king. J $R$ Army Med Corps 1905;4:65-92.

21 Love W. Repatriation of wounded in West Africa. J R Army Med Corps 1945;84:270-1.

22 Bourne AW. Traumatic aneurysm. A series of eight cases from General Hospital, Egypt. J R Army Med Corps 1917:28:276-83.

23 Leiper R, Robert T. Report on the results of the bilharzia mission in Egypt, 1915. J R Army Med Corps 1915;25:1-55.

24 Leiper R, Robert T. Report on the results of the bilharzia mission in Egypt, 1915. J R Army Med Corps 1915;25:147-92.

25 Leiper R. Report on the results of the Bilharzia mission in Egypt, 1915. J R Army Med Corps 1915;25:253-67.

26 Leiper R, Thomson J. Report on the results of the Bilharzia mission in Egypt, 1915. J R Army Med Corps 1916:27:171-90.

27 Leiper R. Report on the results of the Bilharzia mission in Egypt, 1915. J R Army Med Corps 1918;30:235-60.

28 Pilcher R. The basal cell naevus syndrome: a case in the Falkland islands. J R Army Med Corps 1993;139:20-4.
29 McNee J, Renshaw A, Brunt E. 'Trench Fever': a relapsing fever occurring with the British Forces in France. Ournal R Army Med Corps 1916;26:490-524.

30 Hurst A. Trench fever: a relapsing fever occurring among the British troops in France and Salonica. J R Army Med Corps 1917;28:207-19.

31 Hill J. Silent enemies: the story of the diseases of war and their control. G. P. Putnam's Sons 1942

32 Beaman W. Some experiences of a prisoner of war in Germany, with remarks on four prisoners' camps. Ournal R Army Med Corps 1915;25:482-93.

33 Thompson H. An account of my capture and my experiences in Germany. J R Army Med Corps 1915;24:121-36.

34 Unknown. Feeding of prisoners of war in Germany. J R Army Med Corps 1915;24:387-94.

35 Downing T. Breakdown: the crisis of shell shock on the Somme. Hachette UK, 2016.

36 Milligan E. A method of treatment of "Shell Shock". J R Army Med Corps 1917:28:272-3

37 Macmahon C. Shell shock stammering and other affections of voice and speech. J $R$ Army Med Corps 1917;29:192-201.

38 Garton W. Shell-shock and its treatment by cerebrospinal galvanism. J R Army Med Corps 1917:28:600-4.

39 Myers C. Contributions to the Study of Shell Shock:(II) being an account of certain cases treated by hypnosis. J R Army Med Corps 1916;26:642-55.

40 Myers C. Contributions to the study of shell shock (III): being an account of certain disorders of cutaneous sensibility. J R Army Med Corps 1916;26:782-97.

41 Dickson R. Miners' nystagmus and "Shell Shock". J R Army Med Corps 1933;60:454-5.

42 Turner W. Neuroses and psychoses of war. J R Army Med Corps 1918;31:399-413.

43 Collie J. Neurasthenia: what it costs the state. J R Army Med Corps 1916;26:525-44.

44 Roche L. Avertin in anaesthesia. J R Army Med Corps 1934;63:289-95.

45 McKenzie K. Evipan sodium intravenous anaesthesia. J R Army Med Corps 1934;63:45-8

46 Scriven W, Stephens K. Curare as an adjuvant to anaesthesia in military practice. J $R$ Army Med Corps 1948:90:149-54.

47 Raffan A. Blind nasal intubation for endotracheal anaesthesia. J R Army Med Corps 1944;83:145-7.

48 Saleh A. Endotracheal anaesthesia: improved model of Air-Ether bottle. J R Army Med Corps 1944;82:141-3.

49 Stephens KF. Anaesthesia, 1948-1958. J R Army Med Corps 1958:104:159-62.

50 Austin TR, Tamlyn RSP. Ketamine: a revolutionary anaesthetic agent for the battle casualty. J R Army Med Corps 1972:118:15-23.

51 Kmietowicz Z. A century of general practice. BMJ 2006;332:39-40.

52 Donaldson M, Yordy K, Vanselow N. Defining primary care: an interim report. National Academies, 1994

53 Unknown. The enteric fever problem. J R Army Med Corps 1903;1:54-60.

54 Archer G, Ritchie A. Studies on urinary carriage of enteric group organisms. J R Army Med Corps 1950;95:341-61.

55 Archer G, Goffe A, Ritchie A. Studies on urinary carriage of enteric group organisms. J R Army Med Corps 1952;98:125-31.

56 Archer G, Goffe A, Ritchie A. Studies on urinary carriage of enteric group organisms. J R Army Med Corps 1952;98:189-97.

57 Archer G, Goffe A, Ritchie A. Studies on urinary carriage of enteric group organisms. J R Army Med Corps 1952;98:237-40.

58 Archer G, Miller W. Studies on urinary carriage of enteric group organisms. J R Army Med Corps 1952;98:285-91.

59 Archer G. Studies on urinary carriage of enteric group organisms. J R Army Med Corps 1953:99:55-65.

60 Archer G. Studies on urinary carriage of enteric group organisms. J R Army Med Corps 1953:99:87-98.

61 Archer G. Studies on urinary carriage of enteric group organisms. J R Army Med Corps 1953:99:213-27.

62 Palmer P, Reeder M. The imaging of tropical diseases: with epidemiological, pathological and clinical correlation. Springer Science \& Business Media, 2000.

63 World Health Organization. Typhoid vaccines: WHO position paper. Wkly Epidemiol $\operatorname{Rec}$ 2008:83:49-59.

64 Brown K. Pox: the life and near death of a very social disease. The History Press, 2006.

65 Murray JF, Schraufnagel DE, Hopewell PC. Treatment of tuberculosis. A historical perspective. Ann Am Thorac Soc 2015:12:1749-59.

66 Leishman WB. On the possibility of the occurrence of trypanosomiasis in India. BMJ 1903;1:1252-4.

67 Ross R. Further notes on LEISHMAN's bodies. BMJ 1903;2:1401.

68 Cunningham D. On the presence of peculiar parasitic organisms in the tissue of a specimen of Delhi boil. Sci Mem Med Off Army India 1885;1.

69 Njus N. Gunshot wounds—historical perspectives. lowa Orthop J 1985;5.

70 Cernak I. Understanding blast-induced neurotrauma: how far have we come? Concussion 2017;2:CNC42. 